\title{
Uma filmografia colonial de Timor Português
}

A colonial filmography of Portuguese Timor

\section{Maria do Carmo Piçarra}

\section{(2) OpenEdition}

Journals

Edição electrónica

URL: https://journals.openedition.org/aa/1952

DOI: 10.4000/aa.1952

ISSN: 2357-738X

\section{Editora}

Programa de Pós-Graduação em Antropologia Social (UnB)

\section{Edição impressa}

Data de publição: 1 dezembro 2017

Paginação: 133-155

ISSN: 0102-4302

\section{Refêrencia eletrónica}

Maria do Carmo Piçarra, «Uma filmografia colonial de Timor Português», Anuário Antropológico

[Online], v.42 n.2 | 2017, posto online no dia 12 junho 2018, consultado o 18 maio 2021. URL: http:// journals.openedition.org/aa/1952 ; DOl: https://doi.org/10.4000/aa.1952

\section{(c) $(1)(9)$}

Anuário Antropológico is licensed under a Creative Commons Atribuição-Uso Não-Comercial-Proibição de realização de Obras Derivadas 4.0 International. 


\title{
Uma filmografia colonial de Timor Português ${ }^{1}$
}

\author{
Maria do Carmo Piçarra \\ Universidade do Minho e Universidade de Reading
}

O interesse do cinema português por Timor foi tardio. Contrariamente ao que sucedeu relativamente a outras colónias, não é conhecido qualquer registo fílmico deste território durante a monarquia e a Primeira República.

Quando, após o sidonismo, a nova ditadura militar, imposta com a Revolução de 28 de maio de 1926, deu origem ao Estado Novo (1933-1974), a câmara de filmar esteve presente para projectar o regime. A propaganda política levou-a para as colónias africanas, mas as asiáticas - Timor, entre elas - não mereceram atenção. Se a questáo colonial foi determinante para a queda da monarquia e, depois, para a participação portuguesa na Primeira Guerra Mundial, as colónias a Oriente não pareciam uma preocupação para a entáo metrópole - o que não deixa de ser curioso, pois foi a Oriente que o "império" começou a desmoronar com a Uniáo Indiana a reclamar Goa, Damão e Diu a partir da década de 40 do século XX.

Os elevados custos e a falta de infraestrutura de produção de filmes justificam provavelmente o alheamento cinematográfico quanto ao "império a Oriente", mesmo quando o Estado Novo procura legitimar a manutenção de colónias. Em 1951, estas foram transfiguradas em "províncias ultramarinas", operação semântica sustentada por uma retórica luso-tropical simplificada, decorrente da viagem que o sociólogo brasileiro Gilberto Freyre empreendeu, a partir de 1951, pelo "Ultramar", a convite do ministro da tutela, Sarmento Rodrigues. Convidar um teórico para conhecer e escrever sobre o "ultramar" era um investimento consideravelmente mais barato, havendo a expectativa de maiores efeitos quanto à formação de opiniôes favoráveis ao caso português pelas elites diplomáticas e políticas mundiais, que o cinema não lograria alcançar. Do cinema, esperava-se que influenciasse directamente as audiências populares, e essa era outra frente, escamoteada quase sempre no que se refere ao então "Oriente português".

\section{Pioneirismo dos filmes coloniais na propaganda}

Quando ainda estava em definiçáo a política colonial depois consubstanciada no Acto Colonial, a ditadura militar no poder determinou a participaçáo portuguesa nas grandes exposiçóes coloniais europeias e, apesar da crise económica, decidiu produzir filmes coloniais para projectar Portugal e o novo regime internacionalmente. Foi a Agência Geral das Colónias (AGC), criada em setembro de 1924, "para preencher uma falta de informação e de divulgaçáo sobre 
as colónias" (Garcia, 2012:119), a encetar essa produção através do agente geral, Armando Cortesão. Os filmes resultantes, que fixaram Angola, Moçambique, Guiné e S. Tomé e Príncipe - Cabo Verde não foi filmado -, foram apresentados na Exposição Ibero-Americana de Sevilha (1929), na Exposição Internacional e Colonial de Antuérpia (1930) e na Exposição Colonial de Paris (1931).

Os filmes foram criticados negativamente quanto a deficiente conhecimento e identificação dos territórios filmados e em termos artísticos, passando a ser exibidos nas sessóes de propaganda da AGC e pelo Cinema Popular Ambulante, criado em 1935 por António Ferro como instrumento de combate ao comunismo e promoçáo das Casas do Povo. Durante anos, pois, os filmes de propaganda sobre as colónias praticamente desapareceram do circuito comercial de exibição. Uma excepção que confirma a rarefacção foi a do filme I cruzeiro de férias às colónias de África Ocidental (1936), que documenta a viagem de propaganda, com direcção cultural de Marcello Caetano, realizada no verão de 1935, iniciativa da revista Mundo Português, com patrocínio da AGC e do Secretariado da Propaganda Nacional (SPN). À data, porém, o filme - um caderno de viagem filmado - não teve mais do que uma projecção, apesar de realizado pelo mais conceituado fotógrafo de arte de entâo, Manuel San Payo. Rodado ao ritmo acelerado da agenda imposta pela organizaçáo da viagem, ressente-se da precariedade da rodagem, durante a qual não há tempo para focar aspectos humanos para além da sucessão de paisagens e recepçóes pelas administraçóes coloniais.

Não obstante o insucesso desta obra e já durante o período do cinema sonoro, nova Missão Cinegráfica às Colónias de África foi criada, em 1937, pelo Ministério das Colónias, correspondendo a um investimento na produção de filmes de propaganda projectando o esforço colonizador. Nada de novo, porém, quanto à fixação do Oriente. A missáo acompanhou o roteiro da visita presidencial feita por Américo Tomás - a primeira feita desde a monarquia - e não englobou o extremo oriental do império.

Em 1944, o então agente geral das Colónias, Júlio Cayolla, reflecte sobre a propaganda colonial em curso fazendo propostas (1944:34-35):

é de desejar que se acentue e intensifique a propaganda colonial, como elemento formador de uma consciência imperial. E formando-a, mantendo-a e afervorando-a faz-se verdadeira política colonial e auxilia-se a civilização portuguesa.

Concretizando, preconiza-se:

[...]

f) a propaganda pelo cinema, quer com filmes de fundo evocando grandes figuras da nossa história, quer com pequenos documentários em que se veja o actual desenvolvimento das nossas colónias. 
O programa proposto por Cayolla fez escola e o estímulo que a AGC veio dar, no final da década de 40, à produção de documentários de propaganda colonial, através de encomendas aos produtores Felipe de Solms e Ricardo Malheiro, englobou, finalmente, Timor. Refira-se que esse apoio surgiu no âmbito do Programa Marshall e do desígnio assumido de promover a produção das matériasprimas coloniais.

Antes do patrocínio estatal destes documentários, que filmes aludindo a Timor foram feitos? Sobretudo obras relativas às exposiçóes organizadas pelo regime entre 1934 e 1940. Primeira exposição colonial portuguesa (1935), de Aníbal Contreiras, apresenta casas de uma aldeia timorense recriada, em 1934, no recinto da Exposição Colonial do Porto. Noutro documentário, de António Lopes Ribeiro, relativo à homónima Exposição histórica da ocupação do século XIX (1937), mostra-se um mapa de Timor. Do mesmo realizador, Exposiçáo do mundo português (1940) filma uma recriação das casas timorenses assim como os timorenses que vieram participar nas grandes comemorações do duplo centenário, com que o salazarismo celebrou a portugalidade enquanto o mundo estava em guerra. Também em Escola de exposiçóes (1940) - que documenta a participação portuguesa na Exposição de Paris de 1937 e na de Nova Iorque, em 1939 - se alude brevemente a Timor.

Os filmes têm em comum não mostrarem Timor, fixando, sim, como foram trazidos timorenses e elementos culturais representativos para exposição em Portugal. A ida da câmara de filmar a Timor é, pois, tardia e decorrente da guerra.

\section{Ficcionar Timor}

As primeiras filmagens de Timor conhecidas em Portugal não foram feitas por portugueses - são imagens captadas na Segunda Guerra Mundial. Curiosamente, e se Timor não interessou ao cinema português até ao conflito, a referência a essas imagens estrangeiras está publicada numa notícia da revista Cinema sobre um filme de ficção que Fernando Garcia (1917-2008) quis fazer em 1947. Garcia, que em 1942 assistiu Manoel de Oliveira em Aniki Bobó e em 1944 se tornou chefe de produção das Produçóes António Lopes Ribeiro, pretendeu estrear-se na realizaçáo com uma reconstituição cinematográfica do que se passou entre 1941 e 1945.

Tragédia em Timor - o filme que Fernando Garcia vai realizar, narrando em imagens um empolgante argumento de Ferreira da Costa e Dutra Faria - será o primeiro grande documento revelador das realidades timorenses apresentado à consciência e ao brio da gente portuguesa. Sob tal aspecto, Tragédia em Timor 
assume importância muito especial e terá vasta e útil projecção, quer entre nós, quer além-fronteiras. [...]

Conhecemos a sequência literária do filme. Já vimos a sequência cinematográfica. Foi-nos permitido, há dias, folhear a planificação. Por isso, não hesitamos em crer que Tragédia em Timor, uma vez atingidos os anseios manifestados pelos seus técnicos da produção e da realização, será o filme mais arrebatador e (porque não dizê-lo?) mais assustador, até agora produzido no nosso país (Lacerda, 1947:3).

Tomaz de Lacerda, autor do artigo acima citado, escreveu que a produtora seria a Cineditora e que o argumento, do tenente do Exército Ferreira da Costa e do jornalista Francisco de Paula Dutra Faria (1910-1978) - um dos fundadores do nacional-sindicalismo em Portugal -, "teve como alicerces as escrupulosas investigaçóes a que o primeiro procedeu no teatro dos acontecimentos" (1947:3). A fidelidade na reconstituiçáo seria atestada pelo uso de "pedaços de película impressionados pelos próprios japoneses, quando da invasão". Ferreira da Costa tê-los-á conseguido em Timor, onde soube da existência de filmes no local onde estava instalada a secção cinematográfica japonesa. Na mesma, ter-se-á deparado com oficiais japoneses a destruir "milhares de fotografias e os preciosos documentários da invasão de Timor”. Segundo Lacerda,

desesperado, lançou-se para o meio do fogo. Queimou as máos e os braços, mas pôde recuperar fragmentos do precioso material - cujo valor excede tudo quanto possam imaginar os profanos. Os astutos manejos dos nipónicos para continuar na destruição foram eliminados rapidamente com meia dúzia de murros oportunos. Auxiliado por soldados e graduados metropolitanos, Ferreira da Costa salvou pedaços de películas que mostram com nitidez a expedição invasora, a sua chegada em frente de Díli, o desembarque das forças de choque (constituídas por autênticas feras uniformizadas) e até certos lances da luta com as guerrilhas que agiam nas montanhas (1947:3-4).

O artigo, ilustrado com fotografias recolhidas por Ferreira da Costa, relata detalhadamente a intriga. Seria protagonizada por um casal de colonos, "símbolo de toda a população branca de Timor", iniciando-se num cenário idealizado. Atente-se no texto para uma análise do tipo de representaçôes que o filme visaria propor ou, pelo menos, o modo como Lacerda as terá interpretado:

a acção começa em 1941, quando a colónia vivia tranquila, farta e contente, dedicada ao cultivo daquelas terras maravilhosas e ubérrimas. Havia paz e alegria nos lares. Na noite de 19 para 20 de Fevereiro de 1942, de repente, sem qualquer aviso prévio, caiu sobre Díli uma chuva de metralha. Depois, em barcaças motorizadas, surgiram milhares de selvagens amarelos, ébrios de 
rapina e de carnagem. Então, começou a enorme, a indescritível tragédia dos brancos e nativos de Timor, cujo sacrifício estóico serviu para poupar horrores à população de Macau. Houve quem fugisse, levado pela onda do pânico, para terras australianas. Mas houve quem ficasse, conscientemente, suportando todas as angústias, a fome, a doença, enfrentando o espectro da morte lenta, para que jamais se pudesse falar do abandono de Timor pelos portugueses.

Arrastada no turbilhão dos acontecimentos, a família protagonista do filme não consegue manter-se unida. A guerra fracciona-a. Morre, varado pela "catana" de um "atapupo", o seu chefe mais idoso. Os elementos restantes, Sebastiáo e Maria José, casados havia pouco tempo, unidos por carinho sem limites, são separados, e vivem, cada um por seu lado, a odisseia sangrenta da população europeia e indígena, sempre buscando um ensejo para se unirem. Ela, frágil, corpo de mulher animado por alma de rija têmpera, luta, caminha, sofre, estimula os que desanimam, reacende esperanças nos que mostram quebranto. Ele, continuador dos varôes do Século XVI, não recua diante das missões mais árduas, enfrenta os riscos mais temíveis, toma para si as provaçóes mais duras. Em volta de ambos, giram, gemem, combatem, os brancos devotados à continuidade da soberania, e as fidelíssimas turbas dos indígenas, cuja dedicação a Portugal ultrapassou, na verdade, as fronteiras do concebível. Lá surge, na sua luta, na sua paixão e no seu heróico fim, o régulo D. Aleixo. Lá deparamos os lances mais trágicos da odisseia: a sanguinolenta noite do massacre da Companhia de Caçadores, em Ailéu; o martírio dos dois missionários, em Ainaro; o suplício espantoso de um abnegado pegureiro indígena; a tortura dos brancos reunidos na chamada "zona de protecção" de Liquiçá-Maubara.

Por fim, espalha-se a notícia de que se avizinha uma expedição militar portuguesa [...]. Arteiros e rancorosos, os japoneses ainda tentam pôr em prática um plano criminoso, mas os portugueses sobreviventes, embora reduzidos a espectros, minados pela doença, enfraquecidos pela fome, desvairados por tantos e longos sofrimentos, reocupam a colónia, num rasgo de decisão que, só por si, testemunha a continuidade das virtudes tradicionais da gente portuguesa.

Lacerda indica que foi feita uma pesquisa documental profunda para maior rigor das reconstituiçóes, especificando que "foram reunidas milhares de fotos, consultados velhos administradores coloniais especializados em assuntos etnográficos timorenses" (1947:17). Coloca este projecto ao nível de Camões, obra nacionalista assinada por Leitáo de Barros e classificada de "interesse nacional" por Salazar. Não chegou, porém, a realizar-se, desconhecendo-se o paradeiro da película japonesa resgatada.

O desinteresse inicial do cinema de ficção por Timor Português, agravado pela posterior dificuldade de filmar durante a ocupaçáo indonésia de Timor Loro Sae, explica que só recentemente, em 17 de setembro de 2013, tenha estreado a primeira longa-metragem de ficção timorense, A guerra de Beatriz, realizada pela 
timorense Bety Reis e pelo italiano Luigi Acquisto. Falado em tétum, conta a história de Timor-Leste entre 1975 e 2002 através do amor de uma mulher pelo marido e foi filmado quase integralmente na aldeia de Kraras, perto de Viqueque, onde a 17 de setembro de 1983 soldados indonésios perpetraram um massacre.

\section{Olhares do cinema de propaganda do Estado Novo sobre Timor}

A guerra foi sempre determinante para que Portugal assentasse o olhar sobre Timor. A importância dos militares no conhecimento e no registo de Timor Português em imagens é sintomática disso. ${ }^{2}$

Em "Timor e o cinema", Matos-Cruz constata o interesse tardio do cinema português por Timor: "ao contrário do alcance noutros territórios sob administração portuguesa, no Extremo Oriente, o nosso cinema chegou tardio e precário" (2001:162). Refere que uma produção cinematográfica assinalável só surge após a Segunda Guerra Mundial, traduzindo-se em referências à ocupação japonesa de Timor e não incluindo filmagens do território. Não só chegou tarde como foi um cinema oficioso, patrocinado pelo Estado, náo tendo coexistido com uma produção independente.

Em La projection nationale: cinéma et nation, Jean-Michel Frodon (1998) propõe que, no caso das nações modernas, as comunidades não se definem apenas ou prioritariamente para si próprias, mas para as outras naçóes e para o mundo na globalidade. A necessidade de contar as histórias da comunidade a todo o mundo radica na necessidade de reconhecimento daquilo pelo qual a naçáo pretende ser conhecida. Frodon propóe que a cada tipo de comunidade corresponde um tipo de lenda e de narrador e que, para a nação moderna, não há nenhum tipo de lenda mais conveniente do que a lenda filmada e nenhum narrador mais adequado que o cinema. As democracias também fizeram um uso propagandista do cinema, mas os usos feitos pelo cinema soviético, pelo cinema fascista italiano e pelo cinema de propaganda nazi são talvez os mais conhecidos. A ditadura do Estado Novo em Portugal inspirou-se directamente no uso propagandista do cinema por estes três regimes para operacionalizar a sua propaganda nas suas várias declinaçóes, incluindo a colonial.

Além das referências a Timor nos documentários das e para as exposiçóes nacionais e internacionais, a revista mensal de actualidades cinematográficas do regime, Jornal Português (1938-1951), projectou nos ecrãs de cinema duas notícias alusivas a Timor. Em 1946, a edição no 55, de abril, mostra "A chegada a Lisboa dos repatriados de Timor". A narração é expressiva: 
Lisboa viveu, nesse dia, horas da maior emoçáo e assistiu a um dos mais vibrantes espectáculos da sua vida. Depois de tanto sofrimento, depois de tanta amargura, de tanta lágrima e de dias tão tristes para o coração lusitano, Portugal recebe apoteoticamente, enternecidamente, os seus filhos de Timor, que tão longe sofreram nos anos angustiosos da conflagração que assolou o mundo... [...] Em Lisboa, a capital do nosso glorioso império, aclamava os portugueses de Timor, que teimaram em defender a soberania portuguesa, guiados pelo amor pátrio e pela bandeira verde rubra. Que lá longe foi chama irrequieta e ardente de um povo. [...]

Já o no 57 apresenta “Chegou o Quanza de regresso de Timor”, explicando:

[...] no Quanza, que saiu do Tejo em Outubro de 1945, regressava de Timor o contingente militar das Forças Expedicionárias ao Extremo Oriente. No Quanza vieram também dois netos do régulo D. Francisco da Costa Aleixo que, fiel à sua condição de português, foi vítima dos invasores nipónicos. Sorrindo, foram recebidos com afectuosas manifestações por todos e pelos seus futuros companheiros de escola.

Além destas reportagens, alude-se a Timor em duas curta-metragens documentais de 1947: A canonização do beato S. João de Brito e O cortejo histórico com a representação de todos os portugueses em carros alegóricos, de Manuel Luís Vieira. ${ }^{3}$

Um caso interessante é o de dois filmes realizados por Tony Berwald, com produção executiva da Bavaria e produção e patrocínio da Sociedade Agrícola Pátria e Trabalho (SAPT). Fundada em 1897 pelo antigo governador Celestino da Silva, esta empresa produzia e comercializava o produto mais importante da economia timorense, o café arábica, que ultrapassou em importância o negócio do sândalo que, no século XVI, atraiu os "descobridores" portugueses à ilha. Além do café, a SAPT comercializava cacau, óleo de coco e borracha. Daí que, após o fim da ocupação japonesa da ilha, a empresa tenha recorrido à propaganda cinematográfica para promover a sua actividade e mostrar Timor ao mundo.

Mais genérico, Colónia de Timor (1949) mostra a diversidade cultural e geográfica, a recuperação dos edifícios em curso, a retoma das actividades económicas bem como a restauração da ordem pelas autoridades. Destaque para as filmagens, em Maliana, de danças locais, entre as quais a loro sae, em que se encena a decapitação de guerreiros inimigos.

Já Ressurgimento do café em Timor (1950) - que identifica Rogério Oliveira e Silva como autor do texto e Sousa Leal como locutor - ilustra como se processa a exploraçáo do café, do cacau e da borracha. Há preocupação em mostrar que o trabalho na empresa é ordenado, sob as ordens do capataz, e o filme, que reutiliza 
imagens de Colónia, mostra as operaçôes para a exploração e comercialização dos produtos da SAPT. Repetindo um dispositivo habitual nos documentários de propaganda económica, filmam-se o descanso e lazer, apresentando-se danças tradicionais e repetindo a loro sae.

Matos-Cruz é generoso ao abordar a produção documental em Timor, no início dos anos 50, referindo que "se verificaram ciclos documentais, focando a natureza e os costumes, por João Mendes ou Ricardo Malheiro, com os auspícios da Agência Geral do Ultramar (AGU)". Os filmes feitos são insuficientes para considerar-se a existência efectiva de "ciclos documentais": Ecos da visita ministerial ao Oriente (Ricardo Malheiro, 1952), Timor (João Mendes, 1952), Timor, Portugal dos mares do sul (Ricardo Malheiro, 1953), Viagem de Sua Excelência o ministro do Ultramar ao Oriente. Timor (Ricardo Malheiro, 1953) e Portugueses no mundo (João Mendes, 1954) são, segundo Matos-Cruz, os cinco títulos de curta-metragem que estrearam, dos quais só três estão actualmente disponíveis para visionamento no Arquivo Nacional de Imagem em Movimento (ANIM, devido a questóes de preservação ou por não constarem identificados como tal nos arquivos.

Dos três títulos de Malheiros, dois são produção da AGU, denotando logo tratar-se de filmes de propaganda. ${ }^{4}$ Ecos mostraria os tesouros oferecidos ao ministro do Ultramar, Sarmento Rodrigues, na viagem pela "Índia Portuguesa", Macau e Timor. Viagem mostra momentos da viagem do ministro na Índia e em Macau antes de registar a chegada a Díli, e o périplo em que assiste a danças, desfiles de guerreiros e cortejo do trabalho, no decurso do qual condecora resistentes à ocupação japonesa. A narração refere tratar-se da primeira visita de um ministro português à colónia e um desfile de cavalaria timorense é pretexto para alusão às bandeiras portuguesas escondidas pelos guerreiros durante a Segunda Guerra Mundial. Fixa a visita ao monumento dos chacinados de Ailéu, em 1942, e novo desfile, pelos timorenses. O momento alto acontece em Ainaro, de onde o ministro do Ultramar parte, com uma espada oferecida em riste, declarando a narração que Timor é "a mais portuguesa de todas as províncias do Extremo Oriente".

Finalmente, e sem estar identificado como produção da AGU, Timor, Portugal dos mares do sul fixa figuras da presença colonial - sacerdotes e oficiais da Marinha - antes de mostrar, em Vila Salazar, a "dança da pomba", prosseguindo com uma corrida de cavalos, entre um desfile de guerreiros e outra cerimónia colonialista recorrente, um cortejo do trabalho. Filmado em 1952, durante a visita ministerial, abstrai-se da circunstância e não apresenta Sarmento Rodrigues. As imagens são, porém, uma reutilização das de Viagem, excluindo acontecimentos oficiais e explorando o exotismo dos "costumes" timorenses sem deixar de sublimar o "portuguesismo" local. 
Matos-Cruz refere a existência do documentário Timor, atribuído a João Mendes e com produção da AGU, a que não pude aceder no ANIM. De acordo com o historiador, este filme não faz um registo de acontecimentos tão "oficioso", mas propóe uma ideia que outro filme de Malheiro assume claramente no título: que Timor é a presença de Portugal na distante Oceânia. O título do segundo filme de Mendes, Portugueses no mundo, assume um enquadramento ideológico. Não abordando unicamente Timor, quer mostrar o esforço evangelizador, simultâneo com o expansionista, nos Açores, Madeira, Cabo Verde, Guiné, São Tomé, Angola, Moçambique, Índia e Macau, além de Timor.

Em suma, a abordagem da natureza e dos costumes timorenses náo é o objecto desta primeira série de filmes de propaganda mais ou menos explícita, realizada na década de 50. O que se pretende é relevar que, "do Minho a Timor", a presença portuguesa é um facto, resulta de um esforço evangelizador e deriva de uma realidade efectivamente "lusotropical".

Em 1951, Sarmento Rodrigues convidou o sociólogo brasileiro Gilberto Freyre para visitar o "ultramar" português. Em Goa, Freyre deu a conferência "Uma cultura moderna: a lusotropical" e, na sequência da viagem, em 1953, publicou Aventura e rotina e Um brasileiro em terras portuguesas. Data de então o início da apropriação de ideias de Freyre - ou antes, de uma vulgata do lusotropicalismo no âmbito da nova dinâmica reformista da política colonialista de Portugal.

A produção de filmes pela AGU enquadra-se neste processo de adopção, pelo Estado Novo, da teoria de Freyre, ainda que numa versão simplificada, ${ }^{5}$ e respectiva projecção através do cinema.

Produzida esta série de filmes durante a visita do ministro do Ultramar à Ásia - traduzindo o interesse por uma geografia do "ultramar" quase ignorada cinematográfica e politicamente e que surge em plena crise espoletada pela Uniáo Indiana ao reclamar Goa, Damão e Diu -, só no final da década de 50 o cinema do regime voltará a fixar Timor, através do cinema de Miguel Spiguel.

Entre 1959 e 1961, estrearam pelo menos cinco filmes - aludindo ou não explicitamente a Timor no título - que fixam este território. Com patrocínio da AGU e realização atribuída a Miguel Spiguel, Apontamentos turísticos de Timor (1960) fixa elementos da modernizaçáo de Díli, antes de mostrar a pesca artesanal, as belezas do território, a produção de búfalos, as danças tradicionais e as lutas de galo, os cavaleiros de Maubara, os picos do Ramelau, as cenas de caça e as decorações das casas tradicionais.

No Extremo Oriente português (1960) é outro dos títulos filmados, igualmente com patrocínio da AGU, realizaçáo de Spiguel e fotografia de Aquilino Mendes. "Timor [...] terra de estranhas culturas" é como a narração, com texto do "doutor 
Frederico Alves", se refere ao território antes de aludir à diversidade linguística e de etnias e mostrar danças tradicionais: a da cobra e a das toalhas. Após o registo de paisagens, é mostrada uma colona no seu jardim antes da câmara filmar o "aldeamento da raça", com casas tradicionais. Filmam-se aspectos da vida rural, da pesca e da zona turística de Baucau, além do artesanato em tartaruga ou prata. Combates de galos e a dança loro sae são mostrados enquanto o comentário alude aos "dóceis portugueses de Timor" sustentando que a dança "é só folclore".

\section{$O$ arquivo filmado durante a prática antropológica}

$\mathrm{O}$ arquivo colonial que integra obras filmadas durante o Estado Novo no âmbito da prática antropológica é central numa filmografia, não definitiva, para Timor português. Contraponho, aos filmes da Missão Antropológica de Timor (MAT) liderada por António de Almeida ${ }^{6}$ (1900-1984), parte das imagens - 155 minutos ${ }^{7}$ - captadas sob a direcção de Ruy Cinatti ${ }^{8}$ (1915-1986), hoje depositadas ao Museu Nacional de Etnologia (MNE).

Assinale-se que a geógrafa Raquel Soeiro de Brito (n. 1925) também filmou Timor durante a missão de geografia física e humana do "ultramar". Timor (1970-1973) detalha aspectos da paisagem, danças, casas e actividades agrícolas tradicionais, um mercado onde as pessoas sáo mostradas sem estarem em pose, ao contrário do era frequente pedir-lhes, além de fixar pinturas murais numa povoação, pormenores de esteiras, assim como aspectos da erosão na paisagem e tatuagens em mulheres.

Soeiro de Brito recorreu ao cinema para fixar apontamentos visuais e sem preocupação de elaboração em termos de olhar cinematográfico. As imagens, captadas sem planificação ou existência de sequências encenadas, são instantâneos amadores filmados para impressionar aspectos paisagísticos. Notas filmadas no âmbito do trabalho de campo merecem um tratamento específico, que opto por não fazer, centrando-me na análise das diferenças de registo e abordagem patentes nos filmes da MAT e naqueles filmados por e com supervisão de Cinatti.

Vendo os filmes feitos na primeira viagem da MAT, dirigida por António de Almeida, emerge uma questão: trata-se de filmes etnográficos, de filmes científicos ou de registos propagandistas da ciência antropológica praticada nas então colónias portuguesas, ao serviço do regime?

Teresa Castro explica que o cinema etnográfico - "enquadrado pela descrição científica associada à etnologia e à antropologia” (2013:125) - não é habitualmente considerado como pertencendo ao chamado 'cinema científico'". A autora diz que esta segunda designação refere-se, em geral, a um conjunto de 
filmes pertinentes para vários domínios da ciência, como botânica, biologia, geografia, física, meteorologia, medicina, mas não para a antropologia.' Somos, porém, frequentemente confrontados com a questão sobre que critérios definem o filme etnográfico. $\mathrm{O}$ cinema etnográfico é uma das práticas mais contestadas de antropologia visual. Jay Ruby (2011) argumenta que a categorização de filme etnográfico só deve aplicar-se a produçóes de cineastas com formaçáo antropológica combinada com a prática de produção mediática. Castro refere os filmes etnográficos são "produzidos num contexto disciplinar preciso e que procuram documentar no terreno fenómenos culturais e sociais” (2013:125).

Os filmes feitos no âmbito da MAT não se enquadram, pois, na categoria dos filmes científicos nem na dos filmes etnográficos, impondo-se a necessidade de analisar criticamente o uso dos filmes na prática antropológica em Timor avaliando a sua importância no âmbito da política colonial do Estado Novo. ${ }^{10}$

Actividades da missáo antropológica a Timor ${ }^{11}$ enquadra oficialmente a passagem dos cientistas pela ilha. Inicia-se com um desfile de "tipos" timorenses com a Mocidade Portuguesa e tropas locais, empunhando bandeiras portuguesas e fazendo a saudação romana. Prossegue com os cientistas em viagem, de jipe, fixando casas e uma igreja timorenses que denotam influência portuguesa, antes de mostrar timorenses viajando a cavalo. Os contrastes prosseguem: à preparação tradicional do peixe contrapóe-se a casa do administrador colonial, cuja família desce para o terreiro, hesitando entre a pose para a fotografia e a pretensa naturalidade de quem desconhece estar a ser filmado - sucedem-se dois planos de saída da casa (a montagem imperfeita revela repetição do take) que comprovam a encenação do momento. O cenário, idílico, torna-se perturbante quando os cientistas, liderados por Almeida, procedem a mediçóes de crânio e testes sanguíneos de timorenses. $\mathrm{O}$ filme prossegue registando casas, aspectos paisagísticos e actividades económicas tradicionais. A obra é paradigmática de como os filmes da MAT registaram a sua passagem por Timor e retêm a coexistência entre colonos, que impóem a ordem administrativa com suposta brandura, e colonizados, que aclamam a bandeira portuguesa (e que por ela morreram na Segunda Guerra Mundial, proclama-se) enquanto preservam tradiçóes como os jogos e as danças fixados em quatro filmes (Danças e jogos no 1 , no 2, no 3 e Danças de Timor).

Dos três filmes que identificam a MAT no título, refira-se Timor: missão antropológica. Sem som, não dispóe de intertítulos explicativos, tratando-se de uma montagem de sequências em que algumas de natureza mais "antropológica" alternam com outras de registo das visitas oficiais protagonizadas pela MAT e ainda outras, relativas a vistas gerais do território. Numa cerimónia em que a MAT saúda a populaçáo, António de Almeida cumprimenta timorenses 
envergando discos ao peito (é impressionante o modo como lhes toca sem pedir licença). Timorenses com bandeiras portuguesas desfilam em parada militar. Após visita da MAT a um lago, filmam-se actividades quotidianas - um mercado e mulheres a fiar -, uma estaçáo meteorológica e a família que dela se ocupa - aqui surpreende o registo amador, contrastante com o habitual em filmes propagandísticos. Seguem-se vistas da costa e filmagem de casas timorenses. Fixam-se exercícios equestres de timorenses, empunhando bandeiras portugueses filmando-se detalhes da indumentária dos guerreiros e as decoraçóes equinas. Apresentam-se, depois, imagens de timorenses mostrando os dentes e afiando-os com pedra, logo fazendo fogo, as suas roupas tradicionais e os procedimentos para tatuagem antes de retomar-se a filmagem de mercado, com as típicas lutas de galos, além de habitaçóes timorenses. Novas vistas da costa, mais imagens de trajes e danças tradicionais sucedem-se antes de filmar-se o navio onde embarcam membros da missão. Inserem-se, finalmente, imagens das campas de Matias e de Moisés de Sá Benevides antes das despedidas da MAT às autoridades oficiais.

Leitura dos diários de António de Almeida Marques Júnior da primeira viagem no âmbito da Missáo (de agosto de 1953 a 1954) esclarece a natureza pouco científica destes filmes. ${ }^{12}$ Revela que, em geral, o operador, Salvador Fernandes, ${ }^{13}$ trabalha com autonomia dos cientistas e que as filmagens - sem repérage prévia - são feitas com os administradores locais como cicerones. ${ }^{14}$ Referem-se acontecimentos organizados expressamente para serem filmados, como a caçada de Caça e pesca em Timor, ou encenados, como a festa da rainha D. Maria, dos Mambai, na despedida do neto Benjamin, quando este retoma os estudos nos Pupilos do Exército, em Lisboa.

A de 12 de outubro, a entrada no diário de Marques Júnior explica: "por volta das 10 horas reconstituiu-se o jantar de ontem, oferecido pela Rainha dos Mambai, a fim de ser filmado. Quando se acabou era perto do meio-dia”. O facto do jantar ter decorrido a partir das $19 \mathrm{~h}$ e de ter sido reconstituído durante o dia explica-se pela necessidade de luz para a filmagem. Noutras ocasióes, porém, a encenação é no sentido de "ordenar" a realidade, como as filmagens de colégios, mencionadas a 22 de novembro (Poloni, 2012):

no Ossú filmou-se o Colégio Governador Óscar Ruas, de raparigas dirigido por freiras dominicanas, onde estão internadas 137 raparigas, documentandose uma sala de aula a funcionar, o refeitório à hora do almoço e ainda as alunas formadas cantando uma marcha a Portugal. Daqui ainda fomos ao Colégio de Sta. Terezinha, só para rapazes, onde se encontram internados uns duzentos e tal [...], mas como não nos esperavam não estavam preparados para serem filmados. Fomos pois, almoçar a casa do Sr. José Ricardo, já eram $13 \mathrm{~h} 30$. 
Depois do almoço tornámos ao Colégio de Sta. Terezinha, os rapazes já estavam uniformizados, fizeram alguns exercícios, mas o sol fugiu-nos e não puderam ser filmados. Ficou-se de lá voltar um dia desta semana.

Nalguns casos verifica-se uma subordinação do trabalho dos cientistas à participação nos eventos organizados pela administração colonial de modo a serem registados pelo cinema. Disso dá testemunho a entrada, no diário, datada de 4 de novembro (Poloni, 2012):

o Sr. Dr. Almeida partiu para Díli pouco depois das 9 horas e nós fomos na camioneta para uma batida aos búfalos bravios a uns $11 \mathrm{~km}$ daqui que por sinal redundou num fiasco. Máquina cinematográfica e fotográficas a postos, espingardas aperradas e nem um veado apareceu. Quando viemos almoçar eram perto das 15 horas e perdeu-se assim um dia de trabalho.

São 16 os filmes feitos no âmbito da Missão. Além dos referidos, filmaramse Timor - vistas gerais (sem som), Imagens de Timor (sem som), Timor - politica 1 (sem som), Timor - politica 2 (sem som), Timor - politica 3 (sem som), Timor Lautem (sem som), Artes e oficios timorenses (com som), A reconstrução de Timor (com som) e Acção missionária em Timor (com som).

A coexistência de filmes sonorizados e não sonorizados aponta para uma hipótese de trabalho: a de que a primeira categoria foi usada em sessóes de propaganda, e a segunda foi produzida com intuitos mais "científicos" e para uso da Junta de Investigação do Ultramar (JIU).

\section{O arquivo do poeta-cientista Ruy Cinatti}

[...] Eu já cá estou há 10 [meses], graças a mil e um subterfúgios, recusas, fugas para aqui e para ali, e a vontade denodada de estoirar por uma causa em que acredito: a de alçar os timorenses à plena consciência do seu valor moral e intelectual. Entretanto, estou a fazer um filme (ou vários) do qual já filmei, ou dirigi, a filmagem de $6.000 \mathrm{~m}$., e em que Timor há de aparecer em toda a sua riquíssima variedade natural e humana [...]. (Carta a Jorge de Sena, 13/10/62, op.cit.303) (Oliveira, 2003:10)

De outra natureza, complexa, são os filmes realizados em 1962 por Ruy Cinatti. Alexandre Oliveira, na tese de mestrado (e no estudo elaborado durante um estágio no MNE em que analisou e ordenou este acervo), confessa: "se à partida idealizava Cinatti como o tipo ideal de antropólogo que tinha renunciado ao colonialismo português para melhor entender a cultura timorense, cedo entendi que a realidade era muito diferente mas igualmente fascinante" (2006:4). 
Este acervo é composto por 250 bobinas com três minutos de duração cada. Foram filmadas, por Cinatti, com uma câmara portátil de $16 \mathrm{~mm}$ comprada em Macau quando, em abril de 1962, começa a pensar fazer um documentário sobre Timor. O uso do cinema pela etnografia era ainda incipiente e o caso de Margot Dias, que filmou os Maconde em Moçambique em 1961, pode ter sido inspirador, embora seja mais provável a influência directa de Jean Rouch, que, durante a década de 50, mudou a forma da etnografia usar o cinema. O filme etnográfico deixou então de ser um mero "caderno de apontamentos" para se tornar um objecto com existência autónoma, um fim em si. Não está identificada documentação que fundamente o pedido de Cinatti à JIU para que Salvador Fernandes se lhe junte para proceder às filmagens. O certo é que tal sucede. Doze horas de filme, a que se somam mais de mil fotografias, uma dezena de cadernos de apontamentos e vários objectos recolhidos servem de base à escrita da sua tese de doutoramento, com o título provisório "A ecologia, história e cultura material do Timor Português, com especial referência ao habitat das populações nativas". Inacabada, foi preparada durante a frequência do curso de antropologia cultural na Universidade de Oxford. É de assinalar que, quando no final do ano lectivo de 1961, o clube trabalhista local convida Cinatti a proferir uma conferência, que intitulou "The Portuguese position", aborda o colonialismo português sustentando a tese da "tradicional" igualdade racial e é quase omisso quanto aos conflitos emergentes. Posteriormente questiona a sua comunicação e a falta de problematização à mesma pelos pares britânicos em carta, de 11 de junho de 1961, a Krus Abecassis: "fiquei aparvalhado com a reacção, pois hoje ainda não estou certo da verdade de algumas das minhas afirmaçóes, e porque fosse eu um dos meus adversários, saberia o ponto fraco da minha defesa”. Relata Oliveira (2006:82):

por essa razão escreve a Krus Abecassis dando conta do sucedido e avisando que tinha chegado ao limite: "Eu não oculto dizer que, enquanto estava redigindo a minha "fala" estava igualmente engolindo "cobras vivas". [...] Todas estas acusaçóes, ou outras semelhantes, fi-las eu em relação a Timor. [...] Nós somos todos responsáveis pelo que se está passando, mesmo quando a culpa não nos pertence" (carta 11/6/61, op. cit.).

Em A condição humana em Ruy Cinatti, Peter Stilwell cita uma carta de Cinatti a Jorge de Sena, datada de 13 de outubro de 1962, em que explica a sua posição quanto ao progressivo isolamento político de Portugal no mundo e em que se alude igualmente aos filmes (Stilwell, 1995:302): 
em Outubro, Cinatti responde à sugestáo formulada por Jorge de Sena, de vir a leccionar agronomia numa universidade brasileira, e póe definitivamente de parte a hipótese. A explicação fala por si:

"Além da minha idade e de vários deveres de Estado, que me obrigam a Portugal, pelo menos temporariamente, eu morreria de vergonha se abandonasse o meu país numa altura em que todos os outros estáo contra ele. Não gosto de Lisboa, ou do ambiente que lá se respira, mas posso fazer qualquer coisa de directamente útil, quer no campo científico, quer no campo social, aqui em Timor, onde já sou irmão, por pacto de sangue, de muitos timorenses. Tenho de lutar, inclusivamente, com os meus superiores, que à força de me quererem bem, me deixaram vir para Timor apenas por três meses. Eu já cá estou há dez, graças a mil e um subterfúgios, recusas, fugas para aqui e para ali e a vontade denodada de estoirar por uma causa em que acredito: a de alçar os timorenses à plena consciência do seu valor moral e intelectual. Entretanto, estou a fazer um filme (ou vários) do qual já filmei, ou dirigi a filmagem de $6.000 \mathrm{~m}$., e em que Timor há-de aparecer em toda a sua riquíssima variedade natural e humana. [...] Sou considerado homem perigoso, mas em que todos confiam nas ocasióes críticas. De resto, perdi muitas das minhas ambições, que embora escondidas, não deixavam de existir. Isto deu-me uma sensação de liberdade ainda maior do que aquela que era causa de inveja de muita gente conhecida. Sou um homem livre e só tenho medo de mim. [...]".

O programa de realizaçáo dos filmes aparece, pois, subordinado ao desígnio de mostrar Timor em toda a sua "variedade natural e humana". Algumas sequências - o material nunca foi montado - revelam que Cinatti organizou os "décors" das filmagens e deu indicações aos "actores". Não há, porém, nas imagens que tive autorizaçáo para visionar ${ }^{15}$ - cerca de 155', segundo Matos-Cruz em Timor e o cinema $^{16}$ - registo de cerimónias protagonizadas pelas autoridades coloniais. São, efectivamente, apontamentos etnográficos as imagens captadas - as danças, as lutas de galos, as actividades económicas, aspectos da vivência quotidiana, as casas etc. A presença portuguesa é registada não como um fim, mas como algo que existe, está lá, através da fixação das casas dos administradores coloniais, no âmbito dos percursos feitos por Cinatti em Timor, mas que não é objecto de interesse em si.

A montagem que pude visionar inicia-se com imagens da costa timorense (primeira bobina), prossegue com filmagem de casas de antepassados (segunda bobina) e continua com cavalos, nas montanhas, fixando então uma pequena expedição de timorenses, aspectos de telhados de casas antes de mostrar uma mulher a pilar. Seguem-se imagens de cestaria, cultura do tabaco, exploração do coco e venda de cerâmica. É notável a preocupação de fixação dos detalhes, não apenas humanos, mas paisagísticos (terceira bobina). A quarta bobina mostra túmulos e timorenses a fazer representações dos antepassados em madeira, 
denotando o fascínio de Cinatti pela cultura material, também pela inclusão de planos de pormenor dos objectos filmados. Nova bobina, a quinta, documenta um baile em que alguns dos participantes vestem roupas ocidentais. Cinatti é um dos bailarinos. A sexta bobina fixa luta de galos enquanto a sétima mostra a leitura de entranhas de leitão. As danças dos tambores (suai) e dos lenços são fixadas na oitava bobina seguindo-se, na nona, a fixaçáo de loro sae num registo bastante diferente da dos filmes da propaganda (inclusivamente da MAT): mostra cabeças num postes, guerreiros a dançar em seu redor e a decapitá-las. Não só os materiais das cabeças são diferentes; a ritualização é menos ordenada, mais espontânea e sem pose. A bobina 11 mostra pinturas rupestres numa gruta, enquanto a 12 mostra o trilho que conduz até um conjunto de casas tradicionais, revelando pormenores de pinturas murais. A casa de D. Adelino Ximenes (irmão de sangue de Cinatti) e a fixação da grande família deste é tema da bobina 13. Uma panorâmica e detalhes de casas dos antepassados com pinturas murais são mostrados na bobina 14 e a 15 repete o tema, mostrando, porém, casas de uso comum, aspectos construtivos das mesmas, remates dos telhados e altares votivos (lulik).

A bobina seguinte, a 16, mostra o interior de casa e aspectos da construção, mas faz a transicção para outro tema, botânico, apresentando imagens de árvore em flor e detalhes da floraçáo. Estas imagens, embora também comprovem o interesse botânico de Cinatti pela ilha, têm um efeito poético e dialogam com os poemas escritos em Timor. A $17^{\mathrm{a}}$ bobina inicia-se com panorâmica dos campos em socalcos, onde pastam búfalos - segundo Oliveira, foram filmadas no caminho para Baucau -, a que se segue uma sequência de descasque de arroz. Na bobina seguinte mostram-se momentos de lazer num terreiro junto a casa de arquitectura ocidental. A bobina no 20 fixa uma luta de galos no mercado de Baucau. As imagens revelam, porém, a mise en scène, aparecendo Cinatti em campo, a dispor os protagonistas no espaço. Já a bobina 21 mostra o mato e timorenses a cavalo, surgindo Cinatti também montado a cavalo, acenando para a câmara. Prossegue com imagens de casas tradicionais e inclui sequência com menires e uma corrida de barcos na baía de Díli. Uma das bobinas derradeiras, a 23ª, mostra cerimónia de pesca ritual ainda hoje observada em Timor. Trata-se de cerimónia em que é sacrificado um búfalo, que ocorre em agosto na lagoa de Bé-Malai, sendo proibido pescar todo o ano, excepto neste período. A $24^{\mathrm{a}}$ bobina mostra detalhes de poste votivo Mambai e uma casa sagrada em construção (Oliveira identifica-a como localizada na povoação de Aituto), enquanto a seguinte, a 25a mostra danças e festividades nessa localidade. A $26^{a}$ bobina dá-lhe sequência, mostrando administradores coloniais e Cinatti sendo recebidos pelos chefes tradicionais além 
de panorâmica da povoação. A derradeira bobina, 27a , encerra estas sequência captadas em Aituto e fixa casas sagradas e danças.

Luís Miguel Oliveira, crítico de cinema e programador da CP, na folha de sala que acompanhou a projecçáo de filmes sobre Timor, a 1 de julho de 2013, durante a conferência Crossing histories and etnographies, constatou a diferença do olhar de Cinatti: $:^{17}$

"la vraie vie" está, por exemplo, na bela colecção de filmes, mudos e coloridos, que Ruy Cinatti fez em Timor. Em primeiro lugar, são de facto belíssimos, plasticamente belíssimos, seja quando mostram paisagens, ou vegetação, ou gente a trabalhar ou a divertir-se, como num mosaico sobre uma Timor "selvagem", no melhor - no mais livre - sentido do termo. Vistos na sequência dos filmes de teor propagandístico que abrem a sessão, aparecem quase como que uma revelação: tudo o que está em "cativeiro" nesses filmes, encafuado em ideologia e lógica de propaganda, aparece aqui num estado dir-se-ia natural, em nada despojado da sua violência intrínseca (o trabalho duro, as lutas de galos, o sacrifício de animais). Ou pelo menos descomprometido. Descomprometido até com um "olhar etnográfico" típico, esse que António Reis dizia ser (por altura de Trás-os-Montes) "um vício". Sem deixarem de ter um valor etnográfico, são filmes que transcendem a etnografia como disciplina - e nos fazem lembrar, náo é exagero, a justeza tingida de poesia que encontramos naquela náo muito vasta tradição que vai, por exemplo, do Tabu de Murnau (e Flaherty) ao Índia de Rossellini.

Cinatti e Almeida colaboraram no âmbito da MAT dirigida por este último. É, porém, conhecido o afastamento de Cinatti do nacionalismo do regime português, que, em tempos, o entusiasmara - embora, como referido atrás, lhe fosse impossível "abandonar o seu país" quando este estava a ficar isolado internacionalmente. $\mathrm{O}$ certo é que progressivas diferenças políticas e científicas explicam a diferença dos "arquivos filmográficos" fixados sob a orientação dos antropólogos determinantes no estudo de Timor, Cinatti e Almeida. O facto de Cinatti ter valorizado o cinema etnográfico como objecto e de se ter assumido operador do filme que tinha em mente realizar é outro elemento distintivo importante, com implicações quanto às diferenças no tipo de registo filmado e no olhar que documenta. Dado o seu conhecimento do território, desde a década de 40, dispensa cicerones e é, ele próprio, revelador de aspectos até então desconhecidos.

\section{Conclusão}

A ligação entre a prática "científica" e o projecto colonial Estado-novista é assumida nos trabalhos do antropólogo António de Almeida, responsável pela criação da que é a maior colecção de filmes acessível publicamente sobre Timor. 
A dificuldade de acesso aos filmes de Cinatti inviabiliza, de momento, uma avaliação conclusiva sobre a dimensão relativa de um e outro acervo. Que não restem, porém, dúvidas quanto à enorme importância do acervo de Cinatti, tanto quanto ao seu valor fílmico - alguns dos filmes são autênticos poemas visuais em que o olhar do poeta se associa ou impóe ao do investigador - como antropológico, devido à sua natureza não oficiante, ao contrário do arquivo colonial filmado sob a direcção de Almeida. As missôes antropológicas de Almeida em Timor e os filmes resultantes implicam, por isso, o questionamento das instâncias complexas que motivaram umas e outros.

Há, pois, que questionar estes acervos simultaneamente enquanto arquivo integrado num conjunto de práticas de recolha, sistematização, exposição e conservação de informações, e enquanto objectos estritamente fílmicos. Contrariamente à argumentação que (se) sustenta (n)um modelo de objectividade científica, estes filmes não são registos objectivos: seleccionam o que dão ver, optam por um ponto de vista para fazê-lo e - sobretudo - veiculam discursos sobre a realidade. A dimensão "exótica" destes filmes é outro elemento a considerar, decorrente do empolgamento com a viagem de exploraçáo, com as paisagens, e das culturas locais e do "outro". Refira-se a grande diferença no olhar evidenciado nos filmes atribuídos a Almeida ou naqueles filmados por e com supervisão de Cinatti.

Nesse sentido, estes filmes têm de ser abordados também como "imagensclarão" (Benjamim) reveladoras da violência do processo colonial. Uma evidência é que o arquivo filmado antropológico do Timor Português - ainda que escasso se considerado por comparação a outros arquivos relativos a ex-colónias portuguesas (sem arriscar sequer comparações com os de outros impérios coloniais) - tem um peso muito grande na filmografia de Timor até 1975 se considerarmos o espólio de mais de 12 horas de filmes feitos por Cinatti, de acesso por agora condicionado. A importância do arquivo constituído pelos militares, que só perde para a quantificação da produção cinematográfica em Timor Português, não se lhe compara. Muito menos, pode ser referida à escassa produçáo de cinema de propaganda do Estado Novo por via do documentário.

Sublinhe-se, pois, a problematização necessária no âmbito de uma leitura que se impóe começar a fazer sobre o uso dos filmes na prática científica no contexto das missôes antropológicas em Timor e a sua importância no âmbito da política colonial do Estado Novo.

Recebido em 15/03/2017

Aprovado em 12/10/2017 
Maria do Carmo Piçarra é bolseira de pós-doutoramento (Bolsa SFRH/ BPD/93217/2013) da FCT para desenvolver a investigação "Cinema Império. Portugal, França e Inglaterra, representaçóes do império no cinema” no Centro de Estudos Comunicação e Sociedade - Universidade do Minho, e no Centre for Film Aesthetics and Cultures, da Universidade de Reading. Entre outras publicaçóes, é autora de Salazar vai ao cinema, em dois volumes (2006, 2011), e de Azuis ultramarinos. Propaganda e censura no cinema do Estado Novo e coeditora da Aniki: Revista Portuguesa da Imagem em Movimento.

\section{Notas}

1. Este artigo é um resultado do projeto As ciências da classificação antropológica em Timor Português (1894-1975), financiado pela Fundação para a Ciência e Tecnologia de Portugal (Ref. HC/0089/2009).

2. O Centro de Audiovisuais do Exército (CAVE) detém uma colecção de filmes que documentam a presença militar portuguesa em Timor. A dificuldade subjacente ao seu visionamento e estudo reside em não estarem organizados por título, mas digitalizados e reunidos em discos, como blocos de imagens de difícil identificação, quanto à origem e autoria, classificados através de sequências de letras e algarismos. Visionei estes materiais, que analisei sumariamente, concluindo haver necessidade de um trabalho cuidado de identificação dos filmes, e também inventariação da migração de imagens de um filme para vários - refiro-me à reutilização de sequências filmadas usadas em documentários originais que posteriormente originaram versôes mais pequenas, com diferente titulação. Um visionamento mais impressionista - limitado pelas condiçôes técnicas referidas do que necessariamente cuidadoso dos materiais evidencia, porém, os "grandes" temas relativos à presença militar em Timor: 1) preocupação de evidenciar a existência de um exército equipado, usufruindo da infraestrutura necessária, complementado pela existência das tropas de "segunda linha"; 2) divulgação da acção psicossocial, desenvolvida supostamente em prol das populaçóes. Note-se a documentaçấo filmada das dificuldades de circulaçáo e de como o exército age para evitar o isolamento das povoaçôes e quartéis. Dado o enfoque desta publicação, optei por não detalhar este olhar "impressionista" sobre este arquivo.

3. Durante todo o Estado Novo (1933-1974) português, há curtas alusóes a Timor noutros filmes celebratórios do regime, como o documentário de propaganda $O$ jubileu de Salazar (Lopes Ribeiro, 1953), que mostra timorenses desfilando entre "representantes indígenas" num cortejo organizado por Cancela de Abreu, ou Portugal de hoje, (J.N. Pascal-Angot, 1966) que mostra o "mundo português", do Minho a Timor. Também Portugal do meu amor (Jean Mazon, 1967), estilização conseguida devido à composição fotográfica cuidadosa das sequências, pretende mostrar a beleza do país, de Minho a Timor, apresentando paisagens subaquáticas desta ilha, aspectos das casas e teares 
tradicionais antes de filmar a exploração do café. Assinale-se ainda a existência de imagens catalogadas como material de arquivo da AGU, tendo como ano provisório o de 1955, sobre As missóes em Timor.

4. Os filmes de propaganda assumem diferentes formatos, mas são frequentemente documentários, embora possam ser filmados a partir de argumentos ficcionais. São produzidos para convencer o espectador de um determinado ponto de vista político ou para influenciar as opinióes ou o comportamento do espectador.

5. O Estado Novo assimila - adaptando-a e despojando-a da componente sexual - a teoria de Freyre sobre um multiculturalismo assente num denominador comum: a especificidade da adaptação do português e sua cultura a ambientes tropicais. Se o cristianismo português e a "aptidão de transplantador", para os trópicos, dos valores europeus, foram incorporados na ideologia do Estado Novo, a importância dada à mestiçagem e à componente sexual da teoria foram sempre recalcadas.

6. Professor, antropólogo e político, exerceu medicina além de ter assumido a direção do Centro de Estudos de Etnologia do Ultramar, tendo participado em várias expediçóes antropológicas e etnológicas nas ex-colónias portuguesas.

7. 1.708 metros em película de $16 \mathrm{~mm}$.

8. Consultar Castelo (s.d.).

9. Castro afirma que "alguns destes filmes científicos ilustram uma concepção do cinema como instrumento de investigação. Outros (uma grande maioria) são filmes de divulgação, produzidos num contexto pedagógico ou comercial. Por fim, outros são apenas registos de missões de exploração, cujo aspecto mais ou menos arriscado e intrépido os torna um tema cinematográfico ideal" (2013:125).

10. As mais de 12 horas de filmagens dirigidas por Cinatti tiveram acesso condicionado pelo Museu Nacional de Etnologia - a nova direcção empreendeu, entretanto, em colaboração com a Cinemateca Portuguesa, um projecto de edição, em DVD, das mesmas.

11. Há outro filme com o mesmo título, com duração menor. Trata-se de um registo da chegada da missáo e das primeiras impressóes recolhidas pelo operador Salvador Fernandes.

12. Agradeço a Rita Poloni o acesso às notas para elaboraçáo da tese, referida na bibliografia. A partir delas é que acedi aos diários citados (citação sem página).

13. Sabe-se pouco sobre Salvador de Almeida Fernandes. Pesquisa no Arquivo Municipal de Lisboa permitiu identificar uma colecção de fotos de sua autoria, datadas da década de 50 e publicadas em Peregrinaçóes de Lisboa, obra publicada em fascículos e da autoria de Norberto de Araújo (1889-1952). Soeiro de Brito disse-me, em entrevista inédita, que era funcionário de uma loja de fotografia e quem a ensinou a filmar, tendo os dois colaborado nas filmagens da erupção, em 1957, do vulcão dos Capelinhos. 
14. Os filmes relativos a danças e o mencionado Missão são excepçóes que revelam uma articulação entre operador e antropólogos. Ainda assim, o último inclui elementos de pura propaganda colonial.

15. Em janeiro de 2013, fiz um pedido de visionamento ao então director do MNE, Pais de Brito. Em reunião, fui informada de que poderia ver as imagens exibidas publicamente e de que as outras se encontravam em processo de estudo, nomeadamente de identificação dos locais filmados, não podendo ser visionadas por investigadores exteriores ao museu. $\mathrm{Na}$ tese de mestrado, com orientação de Pais de Brito, Oliveira refere o estágio na instituição: "a tarefa do estágio então proposto envolvia a identificação e estudo do acervo documental de Ruy Cinatti legado aquele museu pouco antes da sua morte". Este argumento, relativo a um legado do espólio feito por Cinatti, é contrariado pelo testemunho de Peter Stilwell, que, a 3 de outubro de 2013, respondeu, por email, ao meu pedido de informação, afirmando: "encontrei os filmes entre o lixo da casa de Cinatti, depois de despejada dos seus haveres. Foram entregues ao Museu de Etnologia e depois à Cinemateca para recuperação. $\mathrm{O}$ acesso restrito às cópias enviadas pela Cinemateca para o Museu é uma opçáo que não compreendo".

16. A ficha de visionamento da montagem feita por Oliveira e exibida pelo MNE em sessão pública refere que a mesma tem 59 minutos. O filme ultrapassa, porém, esta descrição e inclui mais sequências que não correspondem às descritas relativamente às bobinas usadas. Apurei junto ao ANIM a duração correcta desta montagem: 971 metros, com a duração de 89 minutos.

17. A sessão, programada pela autora, integrou a projecção de Ressurgimento da agricultura em Timor e A viagem de Sua Excelência o Ministro do Ultramar ao Oriente - 2 Timor [1953].

\section{Referências}

CASTELO, Cláudia. S.d. "Ruy Cinatti". In: Ricardo Roque (ed.). History and Anthropology of "Portuguese Timor", 1850-1975: an online dictionary of biographies. Disponível em: http://www.historyanthropologytimor.org/. Acedido em: 11/5/2017.

CASTRO, Teresa. 2013. "Viagem a Angola: cinema científico e etnográfico". In: Maria do Carmo Piçarra e Jorge António (eds.). Angola, o nascimento de uma nação no cinema. Lisboa: Guerra \& Paz. Vol. 1: O cinema do império. pp. 123-158.

CAYOLA, Júlio. 1944. "A propaganda colonial como elemento de formação duma consciência imperial”. Boletim Geral das Colónias, 228(XX):184.

LACERDA, Tomaz. 1947. "Tragédia em Timor". Cinema, 3-4.

FRODON, Jean-Michel. 1998. La projection nationale: cinèma et nation. Paris: Odile Jacob. 
GARCIA, José Luís Lima. 2012. Ideologia e propaganda colonial no Estado Novo: da Agência Geral das Colónias à Agência Geral do Ultramar: 1924-1974. Tese de doutoramento em História, apresentada à Faculdade de Letras da Universidade de Coimbra.

MATOS-CRUZ, José. 2001. “Timor e o cinema”. Revista Camōes, 14:162-171.

OLIVEIRA, Alexandre. 2003. Os filmes de Ruy Cinatti sobre Timor 1961-1963. Lisboa: Museu Nacional de Etnologia. Policopiado.

. 2006. Olhares sobre Timor: contextos e processos da antropologia para Timor. Dissertação de mestrado, Instituto de Ciências do Trabalho e da Empresa. Policopiado. POLONI, Rita. 2012. Expediçôes arqueológicas nos territórios de ultramar: uma visão da ciência e da sociedade portuguesa do periodo colonial. Tese de doutoramento, Universidade do Algarve.

RUBY, Jay. 2011. "Ethnographic film”. In: Marcus Banks e Jay Ruby (eds.). Made to be seen: perspectives on the history of visual anthropology. Chicago: University of Chicago Press.

STILWELL, Peter. 1995. A condição humana em Ruy Cinatti. Lisboa: Presença. 


\section{Resumo}

O documentário foi o género mais usado pelo Estado Novo para promover o colonialismo português. Embora a produção de filmes etnográficos e científicos não tenha sido tão relevante quanto foi noutros impérios coloniais, há que relevar a importância do uso dos filmes articulado com a prática antropológica em Timor Português. Colóniadistanteepobre,em comparação com Moçambique ou Angola, não interessou o cinema independente, dada a inexistência de condiçóes para a produção cinematográfica no território adicionalmente aos elevados custos da mesma. Foram, por isso, realizados escassos filmes de propaganda, sobretudo no âmbito de visitas políticas ou militares. $\mathrm{O}$ mais importante arquivo de filmes sobre Timor Português surgiu integrado numa prática antropológica e integra duas colecçóes: a composta pelos filmes feitos pela Missão Antropológica de Timor, dirigida por António de Almeida, e a resultante de filmagens do poeta e antropólogo Ruy Cinatti.

\section{Abstract}

The film genre most used by the Estado Novo to promote Portuguese colonialism was documentary. Although the production of ethnographic and scientific films has not been as relevant as it was in other colonial empires, it is important to highlight the relevance of the use of films in the case of the anthropological practice in Portuguese Timor. A distant and poor colony, when compared to Mozambique or Angola, Timor did not interest independent film production, given the lack of conditions for the cinematographic production in the territory in addition to its high costs. Scarce propaganda films were made, mainly in the context of political or military visits. The most important archive about Portuguese Timor is therefore connected to an anthropological practice and comprises two collections: the films produced during the Anthropological Mission of Timor, directed by António de Almeida, and the ones resulting from the filming of the poet and anthropologist Ruy Cinatti.

Palavras-chave: filmes científicos, propaganda, Timor Português, colonialismo, Ruy Cinatti.
Keywords: Scientific films, propaganda, Portuguese Timor, colonialism, Ruy Cinatti. 